\title{
Atypical Aeromonas salmonicida Isolated from Diseased Turbot (Scophtalmus maximus L.)
}

\author{
By J.L. Larsen and K. Pedersen
}

Laboratory of Fish Diseases, Department of Veterinary Microbiology, The Royal Veterinary and Agricultural University, Frederiksberg, Denmark.

\begin{abstract}
Larsen J.L. and K. Pedersen: Atypical Aeromonas salmonicida isolated from diseased torbut (Scophtalmus maximus L.). Acta vet. scand. 1996, 37, 139-146. - Atypical Aeromonas salmonicida were isolated from 3 outbreaks of disease among farmed turbot (Scophthalmus maximus L.) in 3 different farms, 1 from Norway (N1) and 2 from Denmark (DK1 and DK2). In all 3 cases, the incidence of disease and mortality was high and the main characteristic pathological finding was skin ulcers and septicaemia. The isolated bacteria were subjected to a thorough phenotypic and genotypic examination and comparison in the laboratory. All 3 isolates belonged to A. salmonicida but displayed some very different biochemical properties. However, the 2 Danish strains, DK1 and DK2 had identical ribotypes but different from that of N1, whereas the plasmid profiles of DK1 and N1 were identical but different from that of DK2. These observations emphasize the need for an improvement of our understanding of the taxonomy and epidemiology of atypical A. salmonicida.
\end{abstract}

fish; pathogen; furunculosis.

\section{Introduction}

Austin et al. (1989) confirmed the validity of the Aeromonas salmonicida subspecies listed in Bergey's manual (Popoff 1984) and added a description of a new subspecies $A$. salmonicida subsp. smithia to the 3 existing, $A$. salmonicida subsp. salmonicida, A. salmonicida subsp. achromogenes, and Aeromonas salmonicida subsp. masoucida. However, a review of the literature together with new information (Pedersen et al. 1994, 1995, Wiklund et al. 1994) suggest that the proposed subspecies failed to encompass many new isolates of atypical $A$. salmonicida. As far as concerns the growth conditions, they appear to separate into a very fastidious, slow growing group and a group growing like "typical" A. salmonicida subsp. salmonicida (Wiklund \& Dalsgaard 1994).

In the definition of the genus Aeromonas, it is mentioned that Aeromonas occurs in fresh water and sewage (Popoff 1984). However, A. salmonicida subsp. salmonicida has been transferred with smolt of rainbow trout (Oncorhynchus mykiss) and Atlantic salmon (Salmo salar) to sea farms where the organism is a permanent threat to an economical profitable production (Larsen \& Mellergaard 1981, Lillehaug et al. 1992). A. salmonicida can survive for up to 18 months in sediments beneath fish farms (Husevåg \& Lunestad 1995) and be transported to the surface, attached to gas bubbles or lipid droplets, and subsequently to the farmed fish (Husevåg 1991, Enger 1992). Studies of flatfishes such as flounder (Platichthys flesus), dab (Limanda limanda), and plaice (Pleuronectes platessa) have indicated that different atypical $A$. salmonicida are involved in ulcer-disease (Vethaak 1992, Wiklund \& Bylund 
1993, Wiklund \& Dalsgaard 1994), and it has been found that such organisms can enter a fish farm producing turbot and cause a septicaemic infection with the occurrence of ulcers and heavy mortality (Pedersen et al. 1994).

This paper deals with a characterization of isolates of atypical A. salmonicida from 3 outbreaks of disease in turbot farms (1 in Norway and 2 in Denmark) and it also addresses the importance of these organisms from a diagnostic and a forensic point of view.

\section{Materials and methods}

\section{Bacterial isolates}

Atypical A. salmonicida were isolated from pronephros and ulcers of diseased fish from 2 Danish fishfarms (DK1 and DK2) one of which (DK1) was described previously (Pedersen et al. 1994), and isolates were received from collaborative work with a Norwegian production unit - N1 (Gravingen \& Dydland 1991). From DK1, 10 strains were included, isolated from turbot of $50-300 \mathrm{~g}$ body weight. From DK2, only a single isolate was available. Only one fish was submitted to the laboratory for examination and when requesting more specimens, all fishes had been treated with antibiotics due to high daily mortality. These samples were therefore sterile. The fishes from DK2 were juvenile, 5-10 g. From N1, 4 strains were included, all from juvenile fish, 5-10 g.

The type culture strains $A$. salmonicida subsp. achromogenes NCMB 1110 and A. salmonicida subsp. salmonicida NCMB 1102 were used for comparison.

\section{Bacteriological and serological examination}

Initial cultures were made on marine agar (Difco, Detroit, MI, USA), supplemented with $5 \%$ calf blood, and incubated at $20^{\circ} \mathrm{C}$ for $4-7$ days. The isolates were characterized according to the principles and by using the methods out- lined by Dalsgaard et al. (1994), while serological examination of Aeromonas was performed as described by Dalsgaard \& Paulsen (1986). The presence of an A-layer like compound was determined after principles listed by Pedersen et al. (1994).

\section{Protein staining}

The reaction of Aeromonas colonies with Coomassie brilliant blue and Congo red was examined as described by Evenberg et al. (1985) and Ishiguro et al. (1985), respectively.

\section{Plasmid profiling}

Cultures grown in brain heart infusion broth (Difco) for 2-5 days (depending on growth intensity) were used for the determination of plasmid profiles. The plasmids were extracted from the bacteria by the method of Kado \& Liu (1981). Plasmids were separated by gel electrophoresis in 0.6-1.0\% agarose gels (Litex LSL) in TAE (Tris $40 \mathrm{mM}$, sodium acetate $5 \mathrm{mM}$, EDTA $1 \mathrm{mM}$ ) buffer, pH 8.0.

\section{Ribotyping}

Isolation of total DNA was performed according to Pedersen \& Larsen (1993). Restriction enzyme digestion was performed as follows: 5 $\mu \mathrm{l}$ corresponding to $5-10 \mu \mathrm{g}$ of the total DNA solutions was digested with the restriction enzyme HindIII, (Boehringer, Mannheim, Germany) according to the instruction of the manufacturer. Digested DNA was precipitated with $22 \mu \mathrm{l} 7.5 \mathrm{M}$ ammonium acetate and $130 \mu \mathrm{l} 96 \%$ ethanol, centrifuged and resuspended in $20 \mu \mathrm{l}$ distilled water. Ten $\mu$ l loading buffer (EDTA 2 $\mathrm{mM}$ pH 8.0 , bromophenol blue $0.1 \%$, glycerol $30 \%$ ) was then added to the resuspended material and the mixture was subjected to electrophoresis in $0.8 \%$ agarose gels (Litex LSL) in TAE buffer, $\mathrm{pH}$ 8.0. Subsequently, gels were stained with ethidium bromide, $2 \mu \mathrm{g} / \mathrm{ml}$ (Sigma), and photographed at $254 \mathrm{~nm}$ UV tran- 
sillumination. DNA fragments were blotted onto nylon membranes (Hybond-N, Amersham) and fixed to the membranes by baking at $80^{\circ} \mathrm{C}$ for $1 \mathrm{~h}$. Hybridization with a digoxigenin labelled DNA probe complementary to the $16 \mathrm{~S}$ and 23S rRNA of $E$. coli and subsequent detection of hybridized fragments using alkaline phosphatase labelled anti-digoxigenin (Boehringer) and 5-bromo-4-chloro-3-indolyl phosphate and nitroblue tetrazolium (Boehringer) was carried out as previously described (Pedersen \& Larsen 1993).

\section{Results}

\section{Biochemical investigations}

The general properties of the turbot isolates (Table 1) showed that strains from N1 and DK1 were oxidase negative which coincided with a very fastidious growth that was stimulated by the addition of serum. X- or V-factors did not stimulate the growth, nor did elevated $\mathrm{CO}_{2}$ partial pressure as established by the use of "candle jars". The isolate from DK2 was oxidase positive and grew with an intensity like the 2 type cultures. They were all CAMP negative and produced neither hemolysin nor brown pigment. All atypical $A$. salmonicida from turbot appeared to be very hydrophobic like NCMB 1102 as estimated by their growth in broth and on Congo red and Coomassie brilliant blue agar. They also reacted with an $A$. salmonicida subsp. salmonicida antiserum and a purified protein A preparation. Additionally, all turbot isolates were negative in arginine-, lysine-, and ornithine-decarboxylase, arabinose, cellobiose, sorbitol, and lecithin and positive in VP, gelatine, starch, and Tween 80 .

The 2 groups of fastidous atypical A. salmonicida ( $\mathrm{N} 1$ and DK1 isolates) behaved similarly in indole, sucrose, mannitol (negative), esculin, salicin, (positive) and were sensitive to ampicillin and resistant to cephalotin. They behaved, however, differently in glycerol, trehalose, MR, nitrate, where the DK1 and DK2 isolates had identical reactions, and in casein.

The DK2 isolate was oxidase positive, grew on MacConkey agar and differed in the characters indole, esculin, salicin, mannitol and sucrose. In general, the turbot isolates were quite different from the type cultures used for comparison.

\section{Plasmid profiles}

The fastidious isolates from Norway and Denmark (DK1) all possessed 3 plasmids of identical sizes $4.6,7.4$ and $78 \mathrm{~Kb}$, respectively, while the isolate from DK2 harbored 6 plasmids of 4.6, 6.2, 16, 34, 45 and $96 \mathrm{~kb}$ (Fig. 1).

\section{Ribotyping}

The ribotypes of the 3 isolates are shown in Fig. 2. The 2 Danish isolates, DK1 and DK2, had identical ribotypes while the Norwegian strain had a slightly deviating profile.

\section{Discussion}

As previously mentioned, there is still some confusion concerning how many taxa should be recognized within $A$. salmonicida and especially within the atypical group. The present study illustrates this problem, as isolates of atypical A. salmonicida from 3 separate outbreaks of disease among turbot were caused by strains with quite different biochemical behaviour. From 2 outbreaks - one in Norway and one in Denmark - very fastidious strains were isolated. However, upon repeated isolation, strains from the same outbreak were identical in their reactions, but when comparing strains from the 2 outbreaks, they possessed many different characters. Their growth was neither stimulated by $\mathrm{X}$ - and V-factors, nor by elevated $\mathrm{CO}_{2}$ tension, but serum was necessary for their growth. The second Danish isolate displayed a growth modus similar to that of the type strains, but 
Table 1. Biochemical investigation of atypical Aeromonas salmonicida isolated from turbot. General properties.

\begin{tabular}{|c|c|c|c|c|c|}
\hline & \multicolumn{5}{|c|}{ Strain } \\
\hline & N1 & DK1 & DK2 & NCMB 1110 & NCMB 1102 \\
\hline Gram & - & - & - & - & - \\
\hline Motility & - & - & - & - & - \\
\hline Catalase & + & + & + & + & + \\
\hline Oxidase & - & - & + & + & + \\
\hline $\mathrm{O} / \mathrm{F}$ test & $\mathrm{F}^{1}$ & $\mathrm{~F}$ & $\mathrm{~F}$ & $\mathrm{~F}$ & $\mathrm{~F}$ \\
\hline Glucose, gas & - & - & - & - & + \\
\hline Hemolysin & - & - & - & - & + \\
\hline Pigment & - & - & - & - & + \\
\hline Growth in broth & $\mathrm{G}^{2}$ & G & G & U3 & G \\
\hline Serum needed & + & - & - & - & - \\
\hline Growth on MacConkey & - & - & + & + & + \\
\hline Growth at $37^{\circ} \mathrm{C}$ & - & - & - & - & - \\
\hline Congo red & $(+)$ & + & + & - & + \\
\hline Coomassie blue & + & + & + & + & + \\
\hline Agglutination with $A$. salmonicida serum & + & + & + & - & + \\
\hline A-layer & + & + & + & - & + \\
\hline Arginine & - & - & - & + & + \\
\hline Lysine & - & - & - & - & + \\
\hline Ornithine & - & - & - & - & - \\
\hline Indole & - & - & + & + & - \\
\hline MR & - & + & + & - & - \\
\hline VP & + & + & + & + & - \\
\hline Nitrate & - & + & + & + & + \\
\hline Casein & + & - & - & + & + \\
\hline Gelatine & + & + & + & - & + \\
\hline Lecithin & - & - & - & - & + \\
\hline Tween 80 & + & + & + & + & + \\
\hline Glycerol & - & + & + & + & + \\
\hline Arabinose & - & - & - & - & - \\
\hline Mannitol & - & - & + & + & - \\
\hline Sorbitol & - & - & - & - & - \\
\hline Cellobiose & - & - & - & - & - \\
\hline Sucrose & - & - & + & + & - \\
\hline Trehalose & - & + & + & + & + \\
\hline Esculin & late + & late + & - & - & + \\
\hline Salicin & + & + & - & - & + \\
\hline Ampicillin & $\mathrm{S}^{4}$ & $\mathrm{~S}$ & $\mathrm{R}^{5}$ & $\mathrm{R}$ & $\mathrm{S}$ \\
\hline Cephalothin & $\mathrm{R}$ & $\mathrm{R}$ & $\mathrm{R}$ & $\mathrm{R}$ & $\mathrm{S}$ \\
\hline
\end{tabular}

${ }^{1} \mathrm{~F}=$ fermentative

${ }^{2} \mathrm{G}=$ granular

${ }^{3} \mathrm{U}=$ uniform

${ }^{4} \mathrm{~S}=$ sensitive

${ }^{5} \mathrm{R}=$ resistant

All strains were CAMP negative and not stimulated by $\mathrm{X}$ - or $\mathrm{V}$-factor or by increased $\mathrm{CO}_{2}$ tension. 


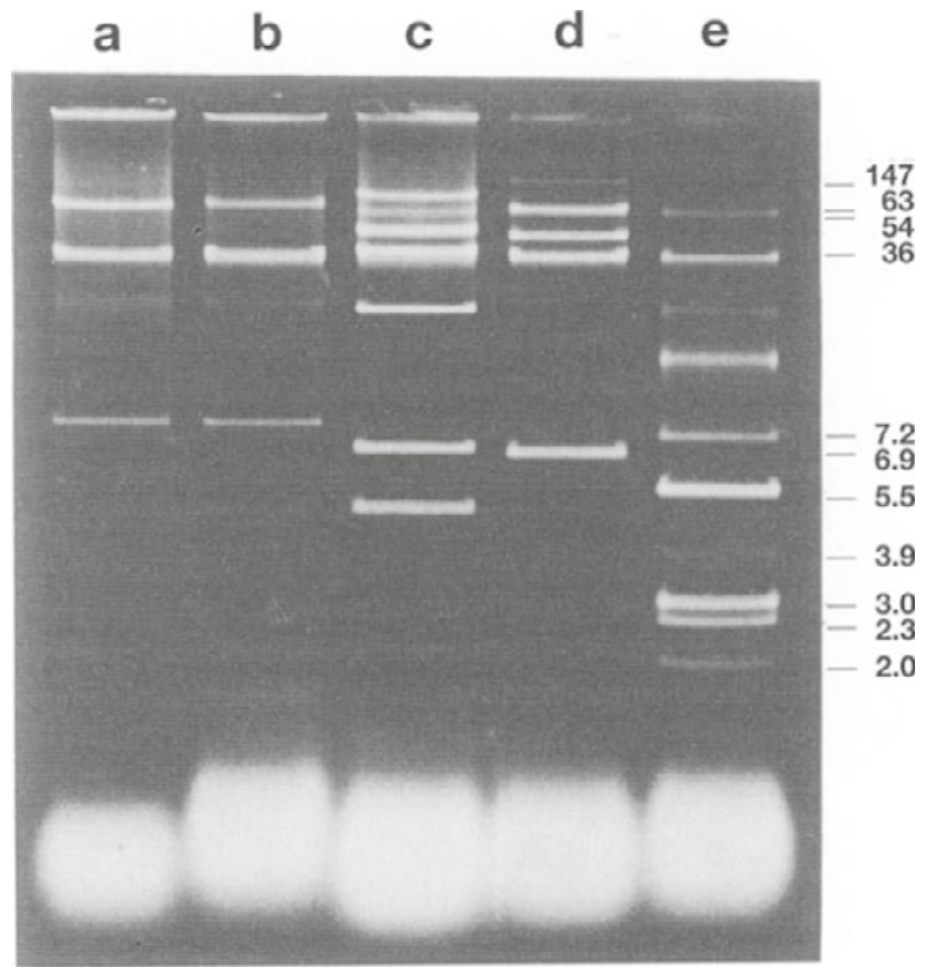

Figure 1. Plasmid profiles of atypical Aeromonas salmonicida isolated from turbot. Lane a: strain 91-2-11 from Norway, N1 (4.6, 7.4, and $78 \mathrm{~kb}$ ); lane b: strain 92-8-149 from Denmark, DK1 (4.6, 7.4, and $78 \mathrm{~kb})$; lane c: strain 92-10-237 from Denmark, DK2 (4.6, 6.2, 18, 34, 45, and $96 \mathrm{~kb})$; lane d: Escherichia coli 39R861 size reference plasmid molecules, 6.9,36, 63, and $147 \mathrm{~kb}$; lane e: $E$. coli V517 size reference plasmid molecules, 2.0, $2.3,3.0,3.9,5.5,7.2$, and $54 \mathrm{~kb}$. The molecular weights of the reference plasmids are marked to the right. The $4.6 \mathrm{~kb}$ band of the $\mathrm{N} 1$ and DK1 strains is very weak.

none of the present strains could be encompassed by the subspecies dealt with in the literature (Austin \& Austin 1993). In general, the turbot isolates shared the properties with $\mathrm{A}$. salmonicida subsp. salmonicida NCMB 1102 with respect to their reaction with antisera against this species, their growth appearence on Congo red and Coomassie brilliant blue agar as well as in the presence of an A-layer like protein. However, in additional characters, significant discrepancies between the present isolates and the subspecies described in the literature (Austin \& Austin 1993) were recorded.

The increasing number of reports dealing with new isolates of atypical $A$. salmonicida from both fresh water and seawater fish in aquaculture makes this group of bacteria very interesting from an epizootiological as well as a taxonomic point of view. However, the epizootiology and pathogenesis are very poorly understood. It might be suggested that feral fish could be actively infected or act as carriers and in this way constitute a pool from which atypical $A$. salmonicida could be transported to different aquaculture systems, infect sensitive populations of fish, and subsequently spread in the system. There is no doubt about the importance of flatfishes as a reservoir for atypical A. salmo- 


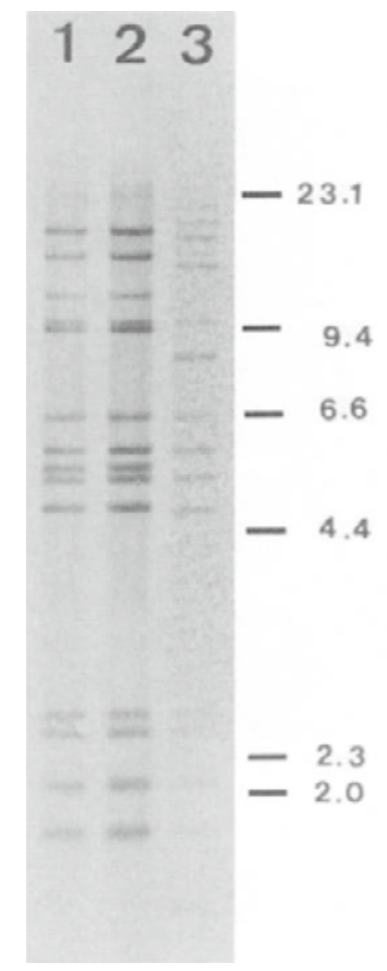

Figure 2. Ribotypes of atypical Aeromonas salmonicida isolated from turbot. Lane a: Strain 92-10-237 from Denmark DK2; lane b: strain 92-8-149 from Denmark DK1; lane c: strain 91-2-13 from Norway N1. The molecular weight markers of HindIII digested $\lambda$ DNA are shown to the right: $2.0,2.3,4.4,6.6$, 9.4 , and $23.1 \mathrm{~kb}$ fragments.

nicida, as skin ulcers in flatfishes are caused by these organisms (Wiklund \& Dalsgaard 1994), and it might be suggested that the 3 outbreaks reported in the present paper were caused by bacteria transported to the aquaculture facilities by the water intake. Genotypic characterization of atypical $A$. salmonicida isolates has shown that they are different in different waters (Wiklund \& Dalsgaard 1995), an observation that also supports the hypothesis that these infections are caused by local strains. Atypical $A$. salmonicida is the only group of $A$. salmonicida causing infections in Iceland (Laxdal 1989), and in Norway they seemed to occur with increasing frequency before the introduction of fish vaccines with oil adjuvants (Steinar Høie, personal communication). It should be emphasized that despite the fact that these atypical $A$. salmonicida share many pathogenic properties with $A$. salmonicida subsp. salmonicida, their epizootiological behaviour is quite different, and they should be regarded differently also from a forensic point of view.

In a recent study, the plasmid profiles and ribotypes of a group of atypical A. salmonicida were investigated (Pedersen et al. 1996). All these strains contained plasmids and almost all strains carried small as well as large plasmids, comparable in size to those detected here from DK1, DK2, and N1 strains. The study of Pedersen et al. (1996) indicated that plasmid profiles as well as ribotypes were very diverse among atypical $A$. salmonicida strains. In contrast, several investigations have shown that plasmid profiles as well as ribotypes of $A$. salmonicida subsp. salmonicida are very homogeneous (Bast et al. 1988, Nielsen et al. 1993, 1994). The study of Pedersen et al. (1996) showed that plasmid profiles could change during an outbreak, indicating that plasmids of atypical $A$. salmonicida can be labile whereas ribotypes were more stable. It is therefore remarkable that the ribotypes of the 2 Danish strains in the present investigation were identical but different from the Norwegian strain, while the plasmid profiles of one Danish isolate was identical to the profile of the Norwegian strain, but different from the other Danish strain. However, the ribotype profiles were similar to other profiles reported in the literature (Pedersen et al. 1996) and likewise, all isolates contained one or more large plasmid and one or more smaller ones, also in accordance with previous reports (Bast et al. 1988, Pedersen et al. 1996).

We conclude that the present status of our knowledge of the importance of the atypical $A$. 
salmonicida still requires a comprehensive study of the taxonomy and ecology of these organisms.

\section{Acknowledgments}

This work was supported by The Danish Agricultural and Veterinary Research Council, grant no. 13-47101. The technical assistance of Mrs. M. Højgård is gratefully appreciated.

\section{References}

Austin B, Austin DA: Bacterial Fish Pathogens: Disease in Farmed and Wild Fish. 2nd ed. pp. 86150. Ellis Horwood Ltd., Chichester, England, 1993

Austin DA, McIntosh D, Austin B: Taxonomy of fish associated Aeromonas spp., with the description of Aeromonas salmonicida subsp. smithia subsp. nov. Syst. Appl. Microbiol. 1989, 11, 277-290.

Bast L, Daly JG, DeGrandis SA, Stevenson RMW: Evaluation of profiles of Aeromonas salmonicida as epidemiological markers of furunculosis infections in fish. J. Fish Dis. 1988, 11, 133-145.

Chapman PF, Cipriano RC, Teska JD: Isolation and phenotypic characterization of an oxidase-negative Aeromonas salmonicida causing furunculosis in coho salmon (Oncorhynchus kisutch). J. Wildlife Dis. 1991, 27, 61-67.

Dalsgaard I, Paulsen H: Atypical Aeromonas salmonicida isolated from diseased sand-eels, Ammodytes lancea (Cuvier) and Hyperoplus lanceolatus (Lesauvage). J. Fish Dis. 1986, 9, 361-364.

Enger Ø: Microbial ecology of marine fish farms, with special emphasis on the fish pathogenic bacteria Vibrio salmonicida and Aeromonas salmonicida. Dr. Scient thesis. University of Bergen, Norway, 1991.

Gravningen K, Dydland M: Sjukdom hos piggvar (Scophthalmus maximus L.). Norsk Veterinærtidsskrift 1991, 103, 923-926.

Husevåg B, Lunestad BT, Johannesen PJ, Enger Ø, Samuelsen OB: Simultaneous occurrence of $\mathrm{Vi}$ brio salmonicida and antibiotic resistant bacteria in sediments at abandoned aquaculture sites. J. Fish Dis. 1991, 14, 631-640.

Husevåg B, Lunestad BT: Presence of the fish pathogen Aeromonas salmonicida and bacteria resistant to antimicrobial agents in sediments from
Norwegian fish farms. Bull. Eur. Ass. Fish Pathol. 1995, 15, 17-19.

Kado CI, Liu S-T: Rapid procedure for detection and isolation of large and small plasmids. J. Bacteriol. 1981, 145, 1365-1373.

Larsen JL, Mellergaard S: Microbiological and hygienic problems in marine aquaculture: Furunculosis and vibriosis in rainbow trout (Salmo gairdneri). Bull. Eur. Ass. Fish Pathol. 1981, 1, 29-32.

Laxdal B: A histopathological comparison of $A$. salmonicida subsp. salmonicida infection in Atlantic salmon (Salmo salar L.) with its ECP and a proteolytic ECP fraction. M.Sc. thesis. The Institute of Aquaculture, University of Stirling, Stirling, Scotland, 1989.

Lillehaug A, Lunder T, Poppe TT: Field testing of adjuvanted furunculosis vaccines in Atlantic salmon (Salmo salar L.). J. Fish Dis. 1992, 15, 485596.

Nielsen B, Olsen JE, Larsen JL: (1993) Plasmid profiling as an epidemiological marker within Aeromonas salmonicida. Dis. Aquat. Org. 1993, 15, 129-135.

Nielsen B, Olsen JE, Larsen JL: Restriction endonuclease analysis (REA) and ribotyping of Aeromonas salmonicida. Dis. Aquat. Org. 1994, 18, 155158.

Pedersen K, Kofod H, Dalsgaard I, Larsen JL: Isolation of an oxidase negative Aeromonas salmonicida from diseased turbot Scophthalmus maximus. Dis. Aquat. Org. 1994, 18, 149-154.

Pedersen $K$, Larsen JL: rRNA gene restriction pattern analysis of Vibrio anguillarum serogroup O1. Dis. Aquat. Org. 1993, 16, 121-126.

Pedersen K, Dalsgaard I, Larsen JL: Characterization of atypical Aeromonas salmonicida isolates by ribotyping and plasmid profiling. J. appl. Bacteriol. 1996,80,37-44.

Popoff M: Genus III. Aeromonas. Kluyver and Van Niel 1936, 398. In: Krieg NR, Holt JC (eds): Bergey's Manual of Systematic Bacteriology, Vol. I, pp. 545-548. Baltimore: Williams \& Wilkins, 1984.

Vethaak AD: Diseases of flounder (Platichthys flesus L.) in the Dutch Wadden sea, and their relation to stress factors. Neth. J. Sea Res. 1992, 29, 257272.

Wiklund T: Atypical Aeromonas salmonicida isolated from ulcers of pike, Esox lucius L. J. Fish Dis. 1990, 13, 541-544.

Wiklund T, Bylund G: A cytochrome oxidase negative bacterium (presumptively an atypical Aeromonas 
salmonicida) isolated from ulcerated flounders (Platichthys flesus (L.)) in the northern Baltic Sea. Bull. Eur. Ass. Fish Pathol. 1991, 11, 74-76.

Wiklund T, Dalsgaard I: Atypical Aeromonas salmonicida associated with ulcerated flatfish species in the Baltic Sea and the North Sea. Dis. Aquat. Org. 1995 (in press).

Wiklund T, Dalsgaard I, Eerola E, Olivier G: Characteristics of "atypical", cytochromeoxidase-negative Aeromonas salmonicida isolated from ulcerated flounders (Platichthys flesus (L.)). J. Appl. Bacteriol. 1994, 76, 511-520.

\section{Sammendrag}

Atypiske Aeromonas salmonicida isoleret fra syge pighvarre (Scophtalmus maximus).

Atypiske Aeromonas salmonicida blev isoleret fra 3 sygdomsudbrud hos pighvar (Scophthalmus maximus L.) opdrættet i 3 forskellige farme, 1 fra Norge (N1) og 2 fra Danmark (DK1 og DK2). I alle 3 tilfælde var både incidencen og mortaliteten høj, og de mest karakteristiske fund var ulcerationer i huden samt septikæmi. De isolerede bakterier blev underkastet en grundig fænotypisk og genotypisk undersøgelse i laboratoriet. Alle 3 isolater hørte til de atypiske $A$. salmonicida, men udviste en række meget forskellige biokemiske reaktioner. Det viste sig imidlertid, at de 2 danske isolater, DK1 og DK2 havde identisk ribotype, som var forskellig fra N1's ribotype, mens plasmid profilerne for DK1 og N1 var identiske, men forskellige fra DK2's profil. Disse observationer understreger behovet for en forbedring af vores forståelse af de atypiske Aeromonas salmonicida isolaters taxonomi og epidemiologi.

(Accepted December 16, 1995).

Reprints may be obtained from: J.L. Larsen, Laboratory of Fish Diseases, Department of Veterinary Microbiology, The Royal Veterinary and Agricultural University, Bülowsvej 13, DK-1870 Frederiksberg C, Denmark. Fax. +45 352827 11, E-mail VETMI@KVL.DK 